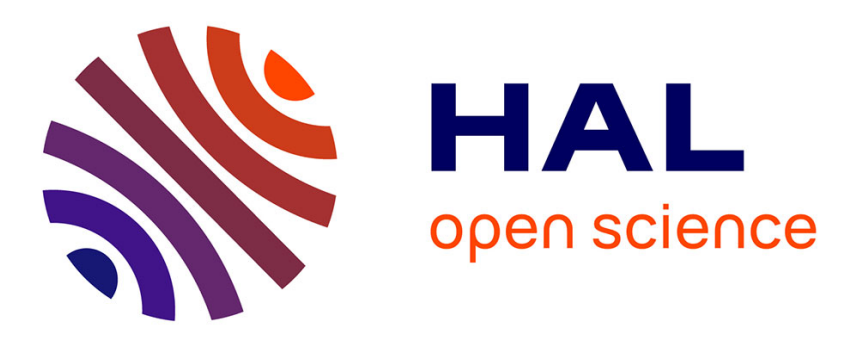

\title{
How important is biogenic isoprene in an urban environment? A study in London and Paris
}

Erika von Schneidemesser, Paul Monks, Valerie Gros, Julie Gauduin, Olivier Sanchez

\section{- To cite this version:}

Erika von Schneidemesser, Paul Monks, Valerie Gros, Julie Gauduin, Olivier Sanchez. How important is biogenic isoprene in an urban environment? A study in London and Paris. Geophysical Research Letters, 2011, 38 (19), pp.n/a-n/a. 10.1029/2011GL048647 . hal-03117255

\section{HAL Id: hal-03117255 https://hal.science/hal-03117255}

Submitted on 6 May 2021

HAL is a multi-disciplinary open access archive for the deposit and dissemination of scientific research documents, whether they are published or not. The documents may come from teaching and research institutions in France or abroad, or from public or private research centers.
L'archive ouverte pluridisciplinaire HAL, est destinée au dépôt et à la diffusion de documents scientifiques de niveau recherche, publiés ou non, émanant des établissements d'enseignement et de recherche français ou étrangers, des laboratoires publics ou privés. 


\title{
How important is biogenic isoprene in an urban environment? A study in London and Paris
}

\author{
Erika von Schneidemesser, ${ }^{1}$ Paul S. Monks, ${ }^{1}$ Valerie Gros, ${ }^{2}$ Julie Gauduin, ${ }^{3}$ \\ and Olivier Sanchez ${ }^{3}$ \\ Received 1 July 2011; revised 29 August 2011; accepted 5 September 2011; published 8 October 2011.
}

[1] As the emissions of anthropogenic volatile organic compounds (VOCs) are reduced through regulatory measures and improved control technologies, biogenic VOCs could gain in importance in terms of reactivity, especially in urban areas. Here we investigate a 12 year record of non-methane hydrocarbons (NMHCs) in central London and the importance of biogenics (in the form of isoprene) for ozone formation through the contribution to $\mathrm{OH}$ reactivity. Significant reductions in NMHCs were observed from 1998 through 2009 at an urban traffic site $(-13 \%$ per year) and suburban background site $(-5 \%$ per year) in London. Total isoprene levels decreased similarly and the relative contribution of isoprene to the total $\mathrm{NMHC} \mathrm{OH}$ reactivity did not change. Furthermore, a dataset for Paris showed strong similarities to the data from London, which would indicate that these results are not limited to London. Interestingly, a rural site to the east of London, Harwell, showed similar contributions of isoprene to the total NMHC reactivity, which may indicate the need for measurements of other biogenic species, such as monoterpenes, in some areas to reliably capture the importance of biogenics in the region. These results would indicate that the influence of biogenic isoprene in London, and likely other low isoprene emitter urban areas have a long way to go before the importance of biogenic VOCs equals or exceeds that of anthropogenic contributions. Citation: von Schneidemesser, E., P. S. Monks, V. Gros, J. Gauduin, and O. Sanchez (2011), How important is biogenic isoprene in an urban environment? A study in London and Paris, Geophys. Res. Lett., 38, L19804, doi:10.1029/ 2011 GL048647.

\section{Introduction}

[2] The importance of biogenic volatile organic compounds (VOCs) to ozone $\left(\mathrm{O}_{3}\right)$ formation owing to their high reactivity in the atmosphere has been recognized for a significant period of time [Chameides et al., 1988]. Chameides et al. found that in some urban areas, such as Atlanta in the United States, biogenic non-methane hydrocarbons (NMHCs; a sub-group of VOCs) contributed significantly to $\mathrm{O}_{3}$ formation, noting that the implicit assumption that anthropogenic emissions were the dominant source of hydrocarbons contributing to $\mathrm{O}_{3}$ production in an urban atmosphere could significantly hinder efforts to reduce $\mathrm{O}_{3}$ if biogenic hydrocarbons were not considered [Chameides et al., 1988].

\footnotetext{
${ }^{1}$ Chemistry Department, University of Leicester, Leicester, UK.

${ }^{2}$ Laboratoire des Sciences du Climat et de l'Environnement, Unité Mixte CEA-CNRS-UVSQ, Gif-sur-Yvette, France.

${ }^{3}$ Airparif, Paris, France.

Copyright 2011 by the American Geophysical Union. 0094-8276/11/2011GL048647
}

Isoprene oxidation also contributes to the formation of secondary organic aerosol (SOA), however, significant uncertainties exist with respect to SOA yields and emission inventories, therefore the focus here will be on the role in ozone formation. While cities like Atlanta do have a significant influence from biogenic emissions, the NMHC reactivity in many urban areas remains dominated by anthropogenic emission sources [Liu et al., 2007; Lou et al., 2010; Song et al., 2008].

[3] More recently, policies requiring emission reduction measures, such as regulation of NMHC emissions from vehicles have successfully reduced anthropogenic emissions of NMHCs in urban areas, as is shown by long-term monitoring of NMHCs in cities like London [von Schneidemesser et al., 2010]. In theory, as anthropogenic NMHCs are reduced, the fractional importance of biogenic NMHCs could increase in importance for ozone formation, especially during times of increased temperature and high photochemical activity [Air Quality Expert Group, 2009; Geddes et al., 2009; Lee et al., 2006]. Isoprene is the single most important compound of non-methane biogenic hydrocarbon emissions globally [Guenther et al., 2006; Pacifico et al., 2009]. Measurements of isoprene (sometimes the only biogenic included in a suite of NMHCs measured) are frequently used to represent biogenic emissions in an area. To investigate the changing influence of biogenic NMHCs versus anthropogenic NMHCs, the trends in isoprene and its contribution to total NMHC reactivity were examined for London and Paris.

\section{Methods}

[4] Hourly non-methane hydrocarbon (NMHC) data was retrieved from the UK Air Quality Archive (www.airquality. co.uk) for three sites (Marylebone Road, Eltham, and Harwell) from January 1, 1998 to December 31, 2009. Data collection, analysis, and QA/QC procedures are discussed by Dollard et al. [2007]. Marylebone Road is an urban traffic site in central London approximately $1 \mathrm{~m}$ from a heavily trafficked road ( $>80,000$ vehicles per day, 6 lanes). Eltham is a suburban background site in greater London directly surrounded by residential and green space. The nearest road is $25 \mathrm{~m}$ from the site and sees much less traffic $(\sim 17,000$ vehicles per day) than the Marylebone Road site. These two sites provide perspectives from two contrasting situations in London, with Eltham more likely to be representative of general conditions in the city as a suburban background site, and Marylebone Road representing those locations highly influenced by traffic emissions.

[5] Harwell is a rural background/agricultural site located roughly 50 miles west of central London surrounded by open 

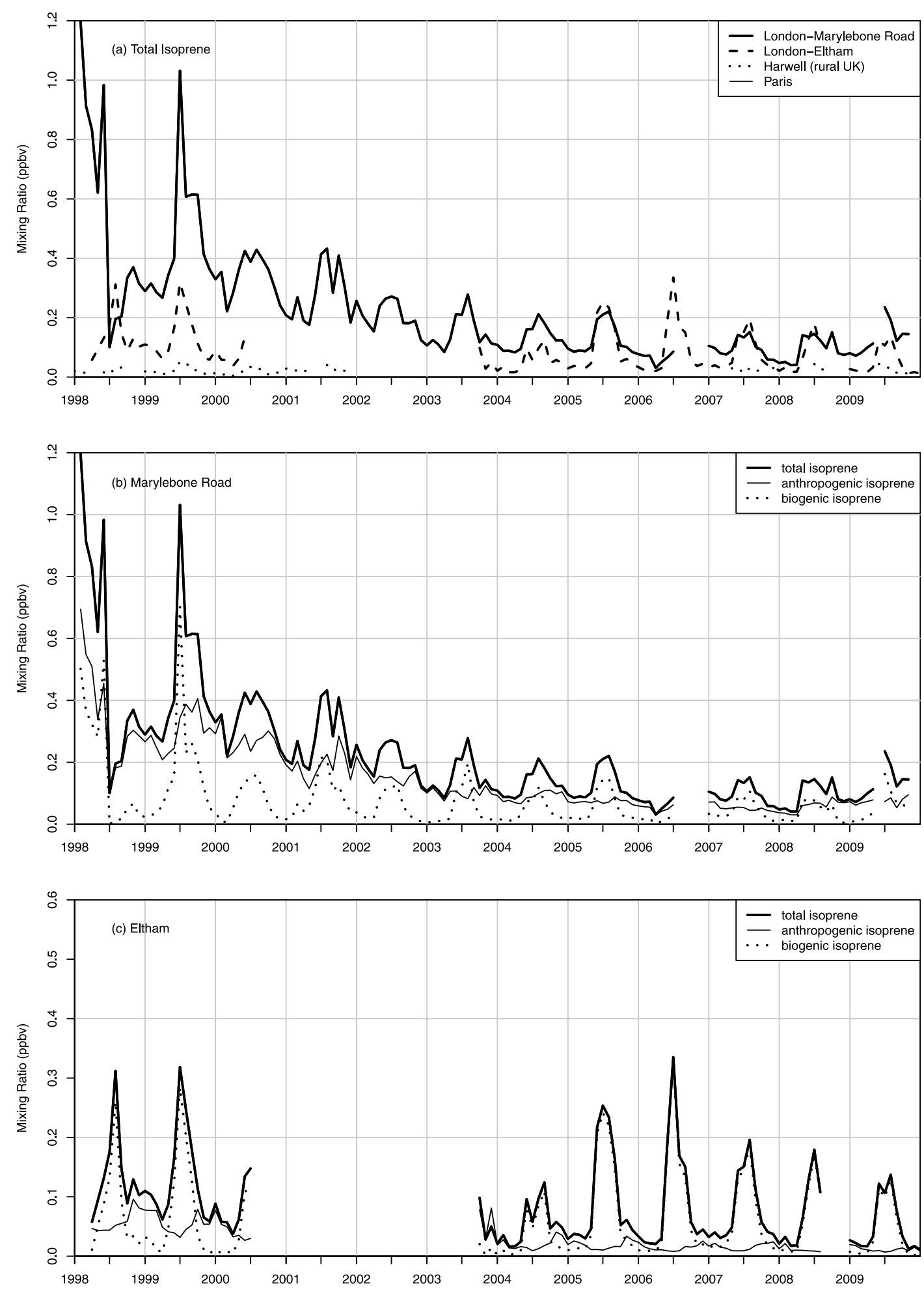

Figure 1. (a) Measured isoprene concentrations for three monitoring sites in the UK and one site in France. Total isoprene and its fractions originating from anthropogenic sources and biogenic sources for (b) the urban traffic site in central London, Marylebone Road, and (c) the suburban background site in greater London, Eltham; note the difference in the y-axis scale for Figure 1c.

green space and no significant roads. The nearest trees are 200-300 m distant. The sampling inlets for all sites are $\sim 3 \mathrm{~m}$ above ground level. Data from Paris were from the 'Les Halles' monitoring site, operated by the air quality network AIRPARIF (http://www.airparif.asso.fr/), located in the first
Arrondissement (central Paris), classified as an urban background site; data was available for 2003 to 2009, inclusive. The monitoring station was in the middle of a small park with the closest busy road ( $>20,000$ vehicles per day) located about $100 \mathrm{~m}$ distant. The sampling inlet was about $3 \mathrm{~m}$ above 
Table 1. Correlations Between Isoprene and Anthropogenic NMHCs Mixing Ratios (ppbv)

\begin{tabular}{|c|c|c|c|c|c|c|}
\hline & \multicolumn{2}{|c|}{ Marylebone Road (Urban Traffic) } & \multicolumn{2}{|c|}{ Eltham (Suburban Background) } & \multicolumn{2}{|c|}{ Paris (Urban Background) } \\
\hline & Winter (DJF) & Summer (JJA) & Winter (DJF) & Summer (JJA) & Winter (DJF) & Summer (JJA) \\
\hline 1,3-butadiene & 0.94 & 0.74 & 0.96 & 0.11 & 0.41 & 0.43 \\
\hline 1-butene & 0.88 & 0.81 & 0.91 & 0.15 & 0.66 & 0.35 \\
\hline Benzene & 0.90 & 0.50 & 0.94 & 0.20 & 0.56 & 0.40 \\
\hline
\end{tabular}

ground level. The data from this site provides a European comparison to the London data, but is not expected to be representative of conditions throughout all of Paris. Nonmethane hydrocarbons measurements, including 28 compounds (from $\mathrm{C}_{2}$ to $\mathrm{C}_{9}$ ), were performed in-situ with a gas chromatograph equipped with a flame ionisation detector coupled to a thermo-desorption unit. Measurements were available every hour and calibrations against a standard are regularly performed. Data are delivered with a $15 \%$ uncertainty. Normalized MEGAN basal emission rates for isoprene were within approximately $10 \%$ of one another for London and Paris indicating similar regional characteristics with respect to biogenic emissions (M. Barkley, personal communication, 2011).

[6] All data processing was done using $\mathrm{R}$ and openair [Carslaw and Ropkins, 2009; $R$ Development Core Team, 2008]. Trends were calculated using the MannKendall function in openair, which calculates a simple linear fit to the natural $\log$ of the data [Carslaw and Ropkins, 2009]. The trends are presented as percent per year changes. 'Total NMHCs' was defined here as the sum of ethane, propane, n-butane, i-butane, n-pentane, i-pentane, 2-methylpentane, n-hexane, n-heptane, 1,3-butadiene, 1-butene, ethene, ethyne, cis- and trans-2-butene, cis- and trans-2pentene, propene, toluene, benzene, ethylbenzene, $\mathrm{m}+\mathrm{p}-$ xylene, o-xylene, and isoprene. Fractional contributions to total NMHCs were calculated for hourly data points only when $\geq 75 \%$ of the compounds were measured.

[7] To parse the anthropogenic from the biogenic contributions to total isoprene for the urban sites in London, a molar ratio of 0.37 (derived previously for London from the mixing ratios of isoprene and 1,3-butadiene) used with the mixing ratio of 1,3-butadiene was applied to determine the anthropogenic portion of the isoprene at the London sites [Derwent et al., 1995; Reimann et al., 2000]. 1,3-Butadiene is emitted almost exclusively from motor vehicles in urban areas, while isoprene has been identified in motor vehicle exhaust in urban areas [Borbon et al., 2001; Derwent et al., 1995, 2000; Reimann et al., 2000]. Additionally, the compounds have similar lifetimes in the atmosphere. The method for the calculation of the ratio is explained in detail by Reimann et al. [2000]. Briefly, the molar ratio is determined from a linear regression of 1,3-butadiene to isoprene from measurements in winter when biogenic isoprene emission potential would be zero, allowing for the estimation of anthropogenic isoprene levels from 1,3-butadiene yearround [Derwent et al., 1995; Reimann et al., 2000]. The published ratio of 0.37 for London is supported by the data from Marylebone Road used in this study, which has a slope of 0.39 for the winter months (DJF) and an $\mathrm{r}^{2}$ value of 0.95 . See Figure $\mathrm{S} 1$ in the auxiliary material. ${ }^{1}$

\footnotetext{
${ }^{1}$ Auxiliary materials are available in the HTML. doi:10.1029/ 2011 GL048647.
}

[8] The relationship between isoprene and temperature was investigated, and as expected showed the non-linear relationship between biogenic isoprene and temperature, as detailed in Lee et al. [2006]. The relationship between anthropogenic isoprene and temperature did not show this same relationship, but a more normal distribution. See Figure S2 in the auxiliary material.

\section{Results and Discussion}

[9] Global biogenic VOC emissions have been estimated at $\sim 600 \mathrm{Tg}$ annually, dwarfing anthropogenic VOC emissions which have been estimated at $98 \mathrm{Tg}$ per year [Guenther et al., 2006; Kansal, 2009; Stewart et al., 2003]. Isoprene is a common tracer for biogenic influence and quantitatively the most important non-methane biogenic VOC on a global level in terms of emissions [Guenther et al., 2006; Pacifico et al., 2009]. However, while isoprene is commonly used as a proxy for biogenics, significant anthropogenic sources of isoprene have been documented in urban areas [Borbon et al., 2001; Reimann et al., 2000]. Monthly average total isoprene mixing ratios are shown in Figure 1a for the three UK sites and Paris. Figures $1 \mathrm{~b}$ and $1 \mathrm{c}$ show the anthropogenic and biogenic contributions at the Marylebone Road and Eltham sites, respectively. The anthropogenic portion was determined using the molar ratio of 0.37 of isoprene to 1,3-butadiene which is emitted almost exclusively from anthropogenic sources [Borbon et al., 2001; Derwent et al., 1995; Reimann et al., 2000] (See Methods section for more details). As expected, the biogenic fraction of isoprene was highest during the summer months, as isoprene emissions are dependent on light and temperature. The anthropogenic fraction was significant year round at the urban traffic site (Figure 1b, Marylebone Road; monthly mean range, all years, anthropogenic isoprene $0.029-0.69 \mathrm{ppbv}$, biogenic isoprene $0.0-0.70 \mathrm{ppbv}$ ), whereas at the suburban background site (Figure 1c, Eltham) the biogenic fraction was generally dominant with the exception of winter (monthly mean range, all years: anthropogenic isoprene $0.0070-0.096 \mathrm{ppbv}$, biogenic isoprene $0.0014-0.33$ ppbv; winter: anthropogenic isoprene $0.0084-0.081 \mathrm{ppbv}$, biogenic isoprene 0.0020 $0.032 \mathrm{ppbv}$ ). As Harwell is not an urban environment with substantial anthropogenic sources, the isoprene was assumed to be mainly biogenic and not separated. The results depicted in Figures $1 \mathrm{~b}$ and $1 \mathrm{c}$ are supported by correlations between total isoprene and 1,3-butadiene, 1-butene, and benzene, three anthropogenic NMHCs emitted primarily from trafficrelated sources in urban areas [Borbon et al., 2001; Derwent et al., 1995, 2000; Xie et al., 2008]. Strong correlations during winter (DJF) were found between total isoprene and these species at both London sites, while the correlations fell off significantly during the summer period, with lesser correlations at Marylebone Road, and no correlation at Eltham (Table 1). Previously, good correlations $(\geq 0.75)$ between 

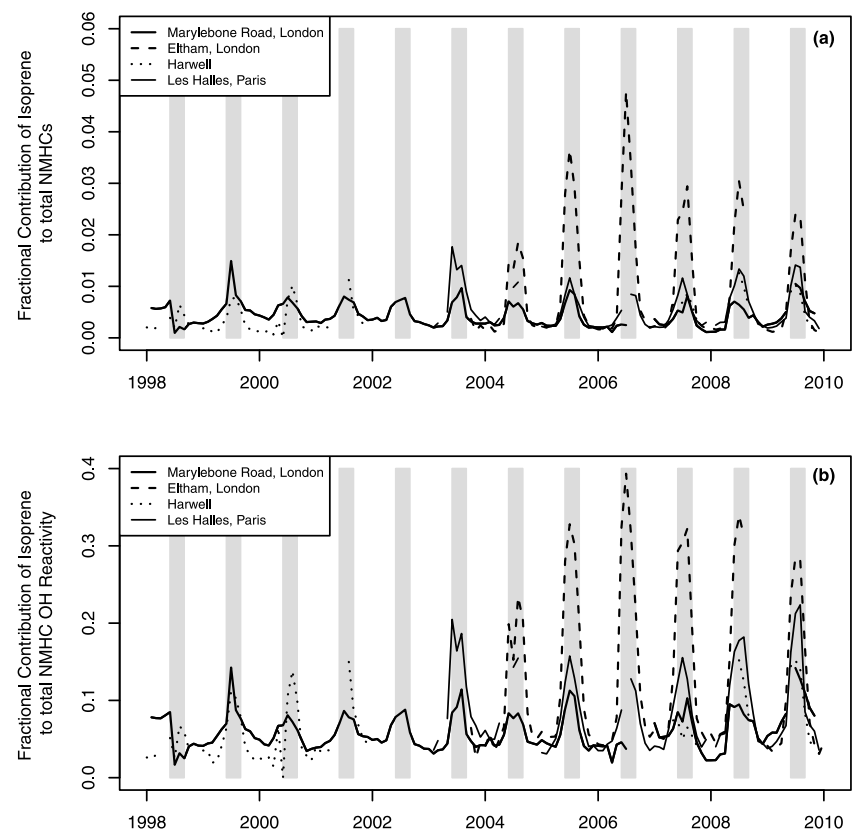

Figure 2. Fractional contribution of isoprene to (a) the concentration of total NMHCs, and (b) the total NMHC reactivity with respect to $\mathrm{OH}$. Total NMHCs are defined as the sum of the 24 NMHCs listed in the methods section. The gray bars highlight the summer months.

isoprene and light alkenes, especially 1-butene, were observed in the urban centre of Bilbao, Spain during the winter period [Durana et al., 2006]. The data from Paris were not separated into anthropogenic and biogenic fractions for two reasons, (1) the 0.37 ratio was determined for London and (2) the correlations between isoprene and the three anthropogenic NMHCs did not show significant differences in winter and summer. The correlation results would seem to indicate that there are significant non-traffic NMHC sources influencing the Paris site.

[10] To assess the importance of isoprene to ozone formation, reactivities with respect to the $\mathrm{OH}$ radical were calculated as in previous studies of VOC reactivity [Gilman et al., 2009; Goldan et al., 2004; Shao et al., 2009]. Total NMHC reactivity was defined as the sum of the reactivities of all 24 compounds included in the total NMHCs as defined in the Methods section. It should be noted that the 24 NMHCs included in the total was by no means a complete list and this should be taken into account when considering the percent contributions to reactivity discussed here. At best these calculations would provide an upper limit to the contribution of isoprene to ambient NMHC reactivity at the sites (Figure 2). $\mathrm{OH}$ rate constants were taken from Gilman et al. [2009, and references therein].

[11] Further support of an anthropogenic contribution to isoprene emissions, especially in winter months, is shown by the diurnal variability of the fractional contribution to $\mathrm{OH}$ reactivity by total isoprene, 1,3-butadiene, 1-butene, and benzene in Figure 3. Although the three anthropogenic compounds show the characteristic morning and evening peaks in mixing ratio as is typically observed in urban areas, the diurnal variation in the fractional contribution of the anthropogenic compounds is minor. As the majority of the compounds show the morning and evening peaks, the frac- tional contributions to the total reactivity remained similar throughout the day. During the winter months, total isoprene followed the same pattern as the anthropogenic species. However, during the summer months, total isoprene had a greater contribution during the afternoon hours, reflecting the influence of biogenic isoprene. While this hourly contribution to $\mathrm{OH}$ reactivity peaked at just less than $12 \%$ at $4 \mathrm{pm}$ for the urban traffic site, total isoprene reactivity dominates the $\mathrm{OH}$ reactivity in the afternoon at the suburban background site, reaching $46 \%$ at $3 \mathrm{pm}$. At the Paris site, total isoprene reactivity peaked at $25 \%$ at $1 \mathrm{pm}$. Measurements at a regional background site in the Pearl River Delta urban agglomeration in China similarly showed that isoprene contributions to $k(\mathrm{OH})$ peaked during the daytime, reaching $70 \%$, but were as low as $20 \%$ during the rest of the 24 hour period (including similar compounds in the total as this study), and that overall the $k(\mathrm{OH})$ was dominated by anthropogenic HCs in large cities [Lou et al., 2010]. A modelling study simulating high ozone episodes over the Po Valley/Milan metropolitan region also found that isoprene emissions were not, on average, a controlling factor for peak $\mathrm{O}_{3}$ concentrations [Liu et al., 2007].

[12] The hourly contributions translate into an average summer reactivity (1998-2009) contribution of $8.7 \%$ and $25 \%$ for Marylebone Road and Eltham, respectively. This percentage contribution falls to $4.4 \%$ and $4.6 \%$, respectively for winter. In comparison, the average summer and winter contributions for Harwell were $10 \%$ and $2.8 \%$, respectively. The urban site in Paris had summer and winter contributions of $16 \%$ and $4.1 \%$, respectively. The winter contribution was similar to the contributions in urban London, and between the two urban sites for summer, as shown in Figure 2. The similarity of the London and Paris data may indicate that the results for London may not be limited to the UK.

[13] While total isoprene never contributes more than 5\% to the total NMHC mixing ratio at any of the sites (Figure 2a), the total isoprene reactivity typically contributes $10-20 \%$ (monthly average data) to total reactivity during summer at Marylebone Road (urban traffic), Harwell (rural), and the suburban site in Paris, and up to $\sim 40 \%$ at Eltham (suburban background) (Figure 2b). One year of measurements in urban Nagoya, Japan found that isoprene contributed approximately $40 \%$ to $k(\mathrm{OH})$ during summer and $10 \%$ during winter [Saito et al., 2009]. (Saito et al. [2009] included 48 NMHCs and were calculated using propylene equivalents, which is a comparable way to determine contribution to $\mathrm{O}_{3}$ production and $\mathrm{OH}$ reactivity.) Measurements in seven cities in Canada during summer attributed approximately $5 \%$ to $15 \%$ of $\mathrm{OH}$ reactivity to isoprene, although significantly more compounds were included than in this study [Stroud et al., 2008].

[14] While the percentage contributions observed in London are not dissimilar to isoprene in other urban areas, it is interesting that the fraction at Harwell, a rural location, is not greater. This may be because of the predominance in emissions from other biogenic NMHC species, such as monoterpenes, as has been suggested to be the case for Great Britain by Stewart et al. [2003], where estimates of annual (1998) biogenic isoprene and monoterpene fluxes were 8 and $83 \mathrm{kt}$, respectively. While the UK may not be a region which is strongly influenced by biogenic VOCs relative to other more forested regions, the inclusion of monoterpene emissions has been found to make a large difference for Europe [Dindorf et al., 2006; Lee et al., 2006]. 


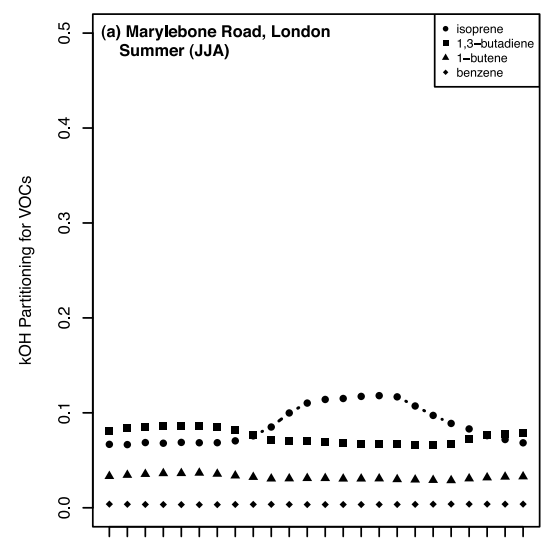

$\begin{array}{llllllllllll}00 & 02 & 04 & 06 & 08 & 10 & 12 & 14 & 16 & 18 & 20 & 22\end{array}$

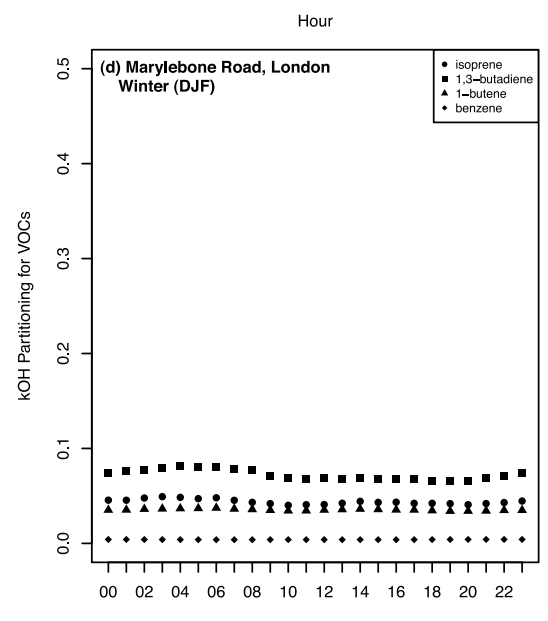

Hour

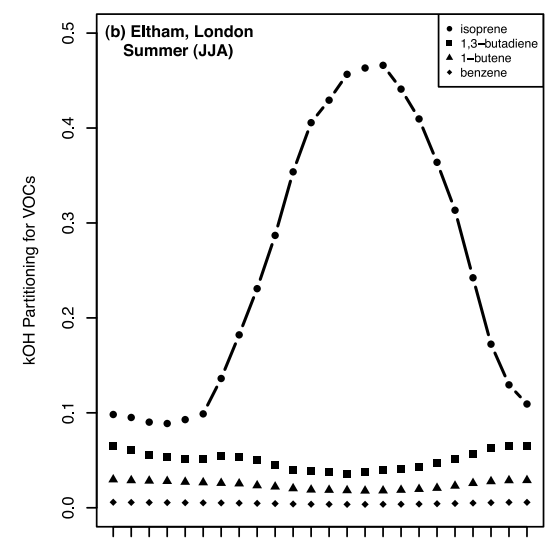

$\begin{array}{llllllllllll}00 & 02 & 04 & 06 & 08 & 10 & 12 & 14 & 16 & 18 & 20 & 22\end{array}$

Hour

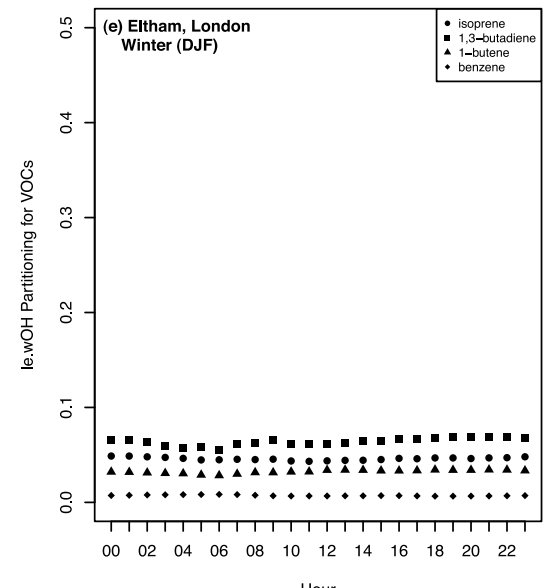

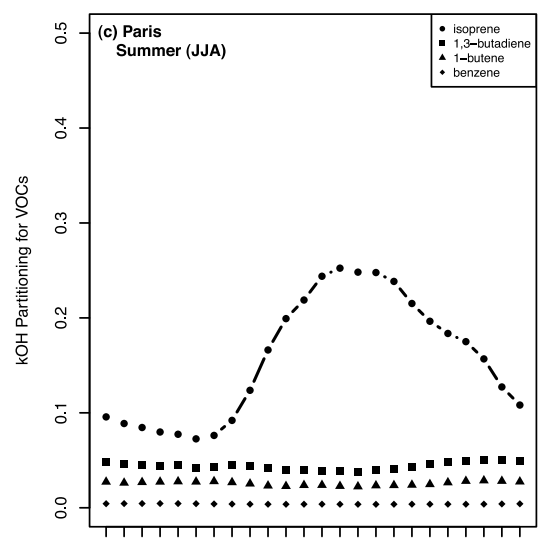

$\begin{array}{llllllllllll}00 & 02 & 04 & 06 & 08 & 10 & 12 & 14 & 16 & 18 & 20 & 22\end{array}$

Hour

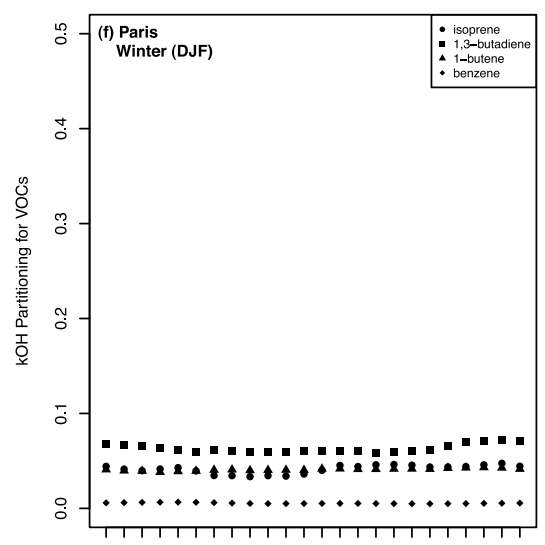

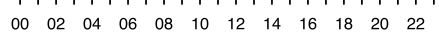

Hour

Figure 3. Average diurnal variability in the fractional contribution of total isoprene and 3 anthropogenic NMHCs to $\mathrm{OH}$ reactivity measured at the urban traffic site in (a and d) central London, Marylebone Road; (b and e) the suburban background site in greater London, Eltham; and (c and f) the urban background site in central Paris, Les Halles. Figures 3a-3c show summer months (June, July, August) and Figures 3d-3f show winter months (December, January, February) for 1998-2009; Paris data is 2003-2009.

[15] To address the theory that as anthropogenic NMHCs are reduced biogenic NMHCs should become much more important, the trends in isoprene (total, anthropogenic, and biogenic) were compared to the trends in the anthropogenic NMHCs at Marylebone Road, Eltham, and Harwell. (Data for Paris exist only for early 2003 onwards and therefore quantitative trends were not comparable.) A summary of the trends are given in Table 2. The total isoprene trend at Marylebone Road was $-17 \%$ per year, while the anthropogenic isoprene showed a stronger decreasing trend $(-20 \%$ per year), and the biogenic isoprene decreased less strongly $(-12 \%$ per year).
In comparison, the three anthropogenic NMHCs with which total isoprene had strong correlations during the winter months, decreased similarly, benzene at $-26 \%$ per year, 1-butene at $-17 \%$ per year, and 1,3-butadiene at $-20 \%$ per year [von Schneidemesser et al., 2010]. Total NMHCs decreased by $-13 \%$ per year. The total isoprene trend ( $-8 \%$ per year) at Eltham was largely driven by the anthropogenic fraction $(-15 \%$ per year), which decreased at a much greater rate than the biogenic fraction $(-3 \%$ per year, not statistically significant). Total NMHCs decreased by $-5 \%$ per year. The trends in the fractional contributions

Table 2. Trends in Total, Anthropogenic, and Biogenic Isoprene and anthropogenic NMHCs ${ }^{\mathrm{a}}$

\begin{tabular}{|c|c|c|c|c|c|c|}
\hline & \multicolumn{2}{|c|}{ Marylebone Road (Urban Traffic) } & \multicolumn{2}{|c|}{ Eltham (Suburban Background) } & \multicolumn{2}{|c|}{ Harwell (Rural) } \\
\hline & Mixing Ratio & OH rxtvty Fraction & Mixing Ratio & OH rxtvty Fraction & Mixing Ratio & OH rxtvty Fraction \\
\hline Total isoprene & $-17 * * *$ & 0 & $-8 * * *$ & 0* & $+3 *$ & $0 * * *$ \\
\hline Anthropogenic isoprene & $-20 * * *$ & $0 * *$ & $-15 * * *$ & $0 * * *$ & - & - \\
\hline Biog. isoprene & $-12 * * *$ & $0 *$ & -3 & $0 * * *$ & - & - \\
\hline 1,3-Butadiene & $-20 * * *$ & $0 * *$ & $-16 * * *$ & $0 * * *$ & $-9 * * *$ & 0 \\
\hline 1-Butene & $-17 * * *$ & $0 * * *$ & $-12 * * *$ & 0 & $+7 * * *$ & $+1 * * *$ \\
\hline Benzene & $-26 * * *$ & $0 * * *$ & $-13 * * *$ & 0 & $-12 * * *$ & $\mathbf{0} * * *$ \\
\hline
\end{tabular}

${ }^{a}$ All trends are percent per year. All statistically significant trends are shown in bold. Three asterisks designate $99.9 \%$ significance; two asterisks designate $99 \%$ significance; one asterisk designates $95 \%$ significance. Numbers not shown in bold designate trends with no statistical significance. 
to $\mathrm{OH}$ reactivity at Marylebone Road and Eltham, however, showed no change for total, anthropogenic, and biogenic isoprene, benzene, 1-butene, and 1,3-butadiene (the total isoprene trend (Marylebone Road) and 1-butene and benzene trends (Eltham) were not statistically significant). This indicates that even at Eltham, where the biogenic isoprene trend showed a far lesser decreasing rate than the anthropogenic fraction, the general decreasing trend in the NMHCs as a whole has resulted in no statistically significant change in the contribution of isoprene to $\mathrm{OH}$ reactivity.

[16] The data for Harwell showed similarly decreasing trends for benzene and 1,3-butadiene, while 1-butene and isoprene were increasing (Table 2). Regardless, the trends in terms of fractional contributions to $\mathrm{OH}$ reactivity still showed no change at Harwell for all compounds except 1-butene, which showed a slight increase in fractional contribution to total $\mathrm{OH}$ reactivity, likely due to its much larger increasing trend. These results would seem to indicate that although regulations and controls on NMHCs have been successful in reducing the anthropogenic emissions, their contribution to $\mathrm{OH}$ reactivity relative to that of biogenic isoprene is still much more important. Significant further reductions in anthropogenic NMHCs would need to take place before the biogenic fraction would be the more important contributor to total $\mathrm{OH}$ reactivity overall in urban areas of low isoprene emissions. While certain conditions (sunlight and high temperatures, as is the case during summer afternoons) can produce significant isoprene emissions and therefore significant ozone forming potential from isoprene, these conditions are limited so that biogenic isoprene is not a dominant ozone forming source for London and the UK.

\section{Conclusions}

[17] The importance of total isoprene to ozone formation potential (considered here in terms of $\mathrm{OH}$ reactivity) was low when considered for larger time scales (e.g., months or longer), $6.0 \%$ at the urban traffic site, $12 \%$ at the suburban background site. At the Paris site, $8.3 \%$ of $\mathrm{OH}$ reactivity was due to isoprene for 2003-2009. Despite significant reductions in anthropogenic NMHCs from 1998 through to 2009, likely owing to effective implementation of emission regulations, the fractional contribution of isoprene to $\mathrm{OH}$ reactivity has not been gaining in importance in the urban environment of London. This is likely due in part to the significant fraction of isoprene in urban areas that originates from anthropogenic sources. Although data for Paris were limited, the mixing ratio and contribution of isoprene to $\mathrm{NMHC} \mathrm{OH}$ reactivity showed significant similarities to the London sites for the last 7 years, suggesting that the role of biogenic isoprene in ozone formation may be limited in other urban environments in northwestern Europe. Significant differences were observed with respect to the fractional importance of isoprene to total $\mathrm{OH}$ reactivity in London when comparing the urban traffic site to the suburban background site, which is not unexpected, but emphasizes the importance of monitoring site placement within urban areas and the implications for assessing the importance of individual NMHCs for ozone production. To reliably assess the influence of biogenic emissions in a region it may be necessary to include the measurement of monoterpene species in routine monitoring, as isoprene, which is frequently used as a proxy for biogenic emissions, may not be sufficient. This would be especially important for regions such as the UK where monoterpenes may be a larger source of biogenic emissions than isoprene overall. These results may have implications for urban air quality policies and monitoring practices, as well as emission inventories used in modelling.

[18] Acknowledgments. This study was funded by the European Commission under the seventh framework programme as part of the CityZen project (212095). The UK monitoring network and data from London were supported by the Air and Environmental Quality Division of the Department for Environment, Food, and Rural Affairs.

[19] The Editor thanks two anonymous reviewers for their assistance in evaluating this paper.

\section{References}

Air Quality Expert Group (2009), Ozone in the United Kingdom, report, Dep. for the Environ., Food and Rural Affairs, London.

Borbon, A., H. Fontaine, M. Veillerot, N. Locoge, J. C. Galloo, and R. Guillermo (2001), An investigation into the traffic-related fraction of isoprene at an urban location, Atmos. Environ., 35, 3749-3760, doi:10.1016/S1352-2310(01)00170-4.

Carslaw, D. C., and K. Ropkins (2009), Open-source tools for analysing air pollution data, report, Inst. for Transp. Stud., University of Leeds, Leeds, U. K.

Chameides, W. L., R. W. Lindsay, J. Richardson, and C. S. Kiang (1988), The role of biogenic hydrocarbons in urban photochemical smog: Atlanta as a case study, Science, 241(4872), 1473-1475, doi:10.1126/ science. 3420404 .

Derwent, R. G., D. R. Middleton, R. A. Field, M. E. Goldstone, J. N. Lester, and R. Perry (1995), Analysis and interpretation of air quality data from an urban roadside location in central London over the period from July 1991 to July 1992, Atmos. Environ., 29(8), 923-946, doi:10.1016/1352-2310(94)00219-B.

Derwent, R. G., T. J. Davies, M. Delaney, G. J. Dollard, R. A. Field, P. Dumitrean, P. D. Nason, B. M. R. Jones, and S. A. Pepler (2000), Analysis and interpretation of the continuous hourly monitoring data for $26 \mathrm{C}_{2}-\mathrm{C}_{8}$ hydrocarbons at 12 United Kingdom sites during 1996, Atmos. Environ., 34, 297-312, doi:10.1016/S1352-2310(99)00203-4.

Dindorf, T., U. Kuhn, L. Ganzeveld, G. Schebeske, P. Ciccioli, C. Holzke, R. Koeble, G. Seufert, and J. Kesselmeier (2006), Significant light and temperature dependent monoterpene emissions from European beech (Fagus sylvatica L.) and their potential impact on the European volatile organic compound budget, J. Geophys. Res., 111, D16305, doi:10.1029/ 2005JD006751

Dollard, G. J., P. Dumitrean, S. Telling, J. Dixon, and R. G. Derwent (2007), Observed trends in ambient concentrations of $\mathrm{C}_{2}-\mathrm{C}_{8}$ hydrocarbons in the United Kingdom over the period from 1993 to 2004, Atmos. Environ., 41, 2559-2569, doi:10.1016/j.atmosenv.2006.11.020.

Durana, N., M. Navazo, M. C. Gomez, L. Alonso, J. A. Garcia, J. L. Ilardia, G. Gangoiti, and J. Iza (2006), Long term hourly measurement of 62 non-methane hydrocarbons in an urban area: Main results and contribution of non-traffic sources, Atmos. Environ., 40, 2860-2872, doi:10.1016/j.atmosenv.2006.01.005.

Geddes, J. A., J. G. Murphy, and D. K. Wang (2009), Long term changes in nitrogen oxides and volatile organic compounds in Toronto and the challenges facing local ozone control, Atmos. Environ., 43, 3407-3415, doi:10.1016/j.atmosenv.2009.03.053

Gilman, J. B., et al. (2009), Measurements of volatile organic compounds during the 2006 TexAQS/GoMACCS campaign: Industrial influences, regional characteristics, and diurnal dependencies of the $\mathrm{OH}$ reactivity, J. Geophys. Res., 114, D00F06, doi:10.1029/2008JD011525.

Goldan, P. D., W. C. Kuster, E. Williams, P. C. Murphy, F. C. Fehsenfeld, and J. Meagher (2004), Nonmethane hydrocarbon and oxy hydrocarbon measurements during the 2002 New England Air Quality Study, J. Geophys. Res., 109, D21309, doi:10.1029/2003JD004455.

Guenther, A., T. Karl, P. Harley, C. Wiedinmyer, P. I. Palmer, and C. Geron (2006), Estimates of global terrestrial isoprene emissions using MEGAN (Model of Emissions of Gases and Aerosols from Nature), Atmos. Chem. Phys., 6, 3181-3210, doi:10.5194/acp-6-3181-2006.

Kansal, A. (2009), Sources and reactivity of NMHCs and VOCs in the atmosphere: A review, J. Hazard. Mater., 166, 17-26, doi:10.1016/j. jhazmat.2008.11.048.

Lee, J. D., et al. (2006), Ozone photochemistry and elevated isoprene during the UK heatwave of August 2003, Atmos. Environ., 40, 7598-7613, doi:10.1016/j.atmosenv.2006.06.057 
Liu, L., et al. (2007), A photochemical modeling study of ozone and formaldehyde generation and budget in the Po basin, J. Geophys. Res., 112, D22303, doi:10.1029/2006JD008172.

Lou, S., et al. (2010), Atmospheric OH reactivities in the Pearl River Delta - China in summer 2006: Measurement and model results, Atmos. Chem. Phys., 10, 11,243-11,260, doi:10.5194/acp-10-11243-2010.

Pacifico, F., S. P. Harrison, C. D. Jones, and S. Sitch (2009), Isoprene emissions and climate, Atmos. Environ., 43, 6121-6135, doi:10.1016/j. atmosenv.2009.09.002.

R Development Core Team (2008), R: A language and environment for statistical computing, R Found. for Stat. Comput., Vienna.

Reimann, S., P. Calanca, and P. Hofer (2000), The anthropogenic contribution to isoprene concentrations in a rural atmosphere, Atmos. Environ., 34, 109-115, doi:10.1016/S1352-2310(99)00285-X.

Saito, S., I. Nagao, and H. Kanzawa (2009), Characteristics of ambient C-2-C-11 non-methane hydrocarbons in metropolitan Nagoya, Japan, Atmos. Environ., 43, 4384-4395, doi:10.1016/j.atmosenv.2009.04.031.

Shao, M., S. Lu, Y. Lu, X. Xie, C. Chang, S. Huang, and Z. Chen (2009), Volatile organic compounds measured in summer in Beijing and their role in ground-level ozone formation, J. Geophys. Res., 114, D00G06, doi:10.1029/2008JD010863.

Song, J., et al. (2008), Comparisons of modeled and observed isoprene concentrations in southeast Texas, Atmos. Environ., 42, 1922-1940, doi:10.1016/j.atmosenv.2007.11.016.

Stewart, H. E., C. N. Hewitt, R. G. H. Bunce, R. Steinbrecher, G. Smiatek, and T. Schoenemeye (2003), A highly spatially and temporally resolved inventory for biogenic isoprene and monoterpene emissions: Model description and application to Great Britain, J. Geophys. Res. 108(D20), 4644, doi:10.1029/2002JD002694.

Stroud, C. A., et al. (2008), OH-reactivity of volatile organic compounds at urban and rural sites across Canada: Evaluation of air quality model predictions using speciated VOC measurements, Atmos. Environ., 42, 7746-7756, doi:10.1016/j.atmosenv.2008.05.054.

von Schneidemesser, E., P. S. Monks, and C. Plass-Duelmer (2010), Global Comparison of VOC and CO observations in urban areas, Atmos. Environ., 44, 5053-5064, doi:10.1016/j.atmosenv.2010.09.010.

Xie, X., M. Shao, Y. Liu, S. H. Lu, C. C. Chang, and Z. M. Chen (2008), Estimate of initial isoprene contribution to ozone formation potential in Beijing, China, Atmos. Environ., 42(24), 6000-6010, doi:10.1016/j. atmosenv.2008.03.035

J. Gauduin and O. Sanchez, Airparif, 7 rue Crillon, F-75004, Paris, France.

V. Gros, Laboratoire des Sciences du Climat et de 1'Environnement, Unité Mixte CEA-CNRS-UVSQ, Orme des Merisiers, Bat. 701, F-91170 Gif-sur-Yvette, France.

P. S. Monks and E. von Schneidemesser, Chemistry Department, University of Leicester, University Road, Leicester LE1 7RH, UK. (psm7@le.ac.uk) 